\title{
Managing an intergenerational workforce as a factor of company competitiveness
}

\author{
Małgorzata Baran \\ Collegium Civitas, \\ Warsaw, Poland \\ malgorzata.baran@collegium.edu.pl
}

\author{
Monika Kłos \\ Pita Academy of Business \\ Poland \\ m.klos@wsb.pila.pl
}

\begin{abstract}
The purpose of this paper is to present the concept of intergenerational cooperation which, in the face of current demographic changes, including the aging population, can provide support for modern business. The concept presented here emphasizes the need to develop intergenerational cooperation in order to keep improving company competitiveness through dispelling myths about the destructive influence that the youngest generation entering the labour market supposedly has on cooperation. The scientific literature on the subject provides many ambiguous definitions of competitiveness, which usually fail to determine the factors necessary to achieve it and, instead, often resort to making comparisons between companies. This vagueness comes from a diversity of approaches to defining the sources of competitive advantage. A review of literature and research conducted among business executives by the authors of this paper allow us to dispel the myths that often lead to discrimination against Generation Y members in the labour market. The study also outlines several areas in which generational diversity management may bring benefits, as well as its impact on building a competitive edge in the following fields: costs, resources, marketing, system organization, creation and communication. This enables to build core competencies in new areas, especially by focusing on the learning process, which results in the acquisition of new knowledge and skills by employees, improving existing skill and knowledge levels, as well as introducing the principle of knowledge management. As a result, better conditions for the development of resources and new ways of their configuration are provided which, in turn, serves as a basis for the creation and development of core competences in the company.
\end{abstract}

Keywords: competitive advantage, labour management, generational diversity and cooperation, companies

JEL Classification: O20, J24, J53, J54 


\section{INTRODUCTION}

In the context of increasing globalization and regionalization of the economy, the conditions in which businesses operate and, consequently, their competitiveness are increasingly dependent on actions taken by various entities operating in their business environment. When assessing the determinants of business competitiveness we must note the significance of core competencies, currently ranked among the most important factors affecting the company's position in the market. In recently published literature on the subject, the term "human resources" is increasingly often replaced by "human capital", which may indicate awareness of the status and importance of the human factor in the era of a knowledge-based economy. Moreover, there has been a widespread belief that the employees' knowledge, skills and attitudes are values that enable the company to acquire and maintain a sustainable and unquestionable competitive advantage.

Having a diverse team allows you to more effectively acquire and keep customers, which translates into better financial condition of the company. More than $83 \%$ of HR directors says that having a diverse team allows you to more effectively raise the number of regular customers, which translates into better financial standing firm in the direction of the knowledge economy ${ }^{1}$. Meanwhile, the nationwide study on the use of the model of diversity management in business, shows that only $21 \%$ polish companies implement this type of solution, and $19 \%$ have formal procedures concerning cooperation in diverse teams ${ }^{2}$.

\section{SELECTED ASPECTS OF COMPANY COMPETITIVENESS}

Worldwide technological progress causes considerable changes in the significance of different factors of production. The role of traditional production factors, such as natural resources, climate, location, workforce skills and capital, is still very profound. However, as a consequence of successive industrial revolutions, other factors are becoming increasingly important. These include communication infrastructure and qualifications of managerial staff (which is an important component of the company's intellectual capital). In order to achieve a competitive advantage, companies use hard and soft resources. "Hard" resources include capital, technology, clear-cut long-term strategies and an effective organizational structure. "Soft" factors include the company's socio-economic environment, which encompasses knowledge and education levels (Koźmiński, 2004).

One of the most comprehensive approaches to the assessment of a company's competitive position is that of Z. Pierścionek, who notes that "from the stakeholders' point of view, [an organization] is deemed to be competitive among a group of companies, if it achieves the stakeholders' goals at a desirable level and/ or has the potential to achieve these goals in the future" (Pierścionek, 2003). In his view, the evaluation of a company's competitive position should involve examining, among other factors, the quality of resources and competences (i.e. skills) of the company's employees.

The changes that are currently taking place in organizations, resulting primarily from globalization caused by increased competition in the international market, changes in cultural patterns, as well as higher education and career aspirations of employees, make the traditional sources of competitive advantage less effective which, in turn, leads to changes in how companies compete with each other (Dwojacki, Nogalski,

1 Raport Economist Intelligence Unit (EIU) - nt. różnorodności w biznesie, available at www.linkedin.com/company/ linkleaders-communication-\&-consulting, referred on 2014-05-15.

2 Raport Barometru różnorodności (I), available at www. diversityindex.pl/Content/uploaded/files/DI_Barometr_Roznorodnosci_raport(1).pdf, referred on 2014-05-10. 
Sikorski, 1999). In the contemporary economic reality, competitive advantage is determined, among other factors, by:

- the core competences that define and support the development of distinctive capabilities, processes and resources and, at the same time, weaken the status of actions that do not create added value,

- continuous improvement through a learning process,

- cooperation with partners (e.g. suppliers, customers) and complementing one's own competences with those of a partner (Bratnicki, 2000):

Performing tasks based on these sources of competitive advantage requires a focus on intangible resources, notably on knowledge. This often entails introducing a radical change in the way the company is managed. The challenge for managers is to create a range of unique competencies that will give the company a competitive advantage.

\section{THE SIGNIFICANCE OF CORE COMPETENCES IN THE PROCESS OF COOPERATION}

The concept of competency-based competition forms one of the competence based perspective theories. It focuses on the analysis of an organization's interior, where sources of competitive advantage are believed to originate.

Among the pioneers of the competency-based competition concept, a prominent role is played by the authors of The Core Competence of the Corporation, a paper in which they explained the essence of core competences. The authors defined the term as collective learning in the organization, particularly in coordinating diverse production skills and integrating multiple streams of technologies. Core competences consist of communication, commitment and dedication of employees at multiple levels and functions. They determine the direction of future operations and drive the development of new businesses (Prahalad, Hamel, 1990).

Other authors suggest that core competences are sets of skills and expertise rather than products and features. They are primarily of intellectual nature and relate to the entirety of the company's operations (Quinn, Hilmer, 1994). Maintaining a competitive edge requires managing the combination of competences available to the company.

- A.B. Escrig-Tena and J.C. Bou-Llousar developed a set comprising mainly soft skills:

- leadership - competences in this area include the ability of superiors to articulate and communicate the vision and strategy of the company, and to support subordinates in achieving these goals,

- taking advantage of the company's environment - focusing on the client provides information about the business environment,

- developing the employees' know-how - creating conditions conducive to the employees' creativity, which at the same time enriches their work,

- external cooperation skills - forging partnerships with clients and suppliers,

- creating a collaborative mind - taking actions conducive to teamwork,

- commitment to the company - taking actions conducive to identification with the goals and values recognized as important in the organization,

- stimulating the learning process in the organization - acting in line with highly structured problemsolving processes and creating good conditions for teamwork, which fosters learning in the company (Łoboda, Sitko-Lutek, 2007).

Organizational structures that enable the creation and development of core competencies as a source of competitive advantage include the network organization, the learning organization and the intelligent 
organization. In such organizations, activities are focused on mental capabilities, because they are more relevant to achieving a competitive edge than any physical abilities. A key role is played by the learning process and its results depend primarily on the ability to use intellectual capital. In such organizational forms, work is organized in line with different principles (than in more traditional forms). Also, the requirements concerning employees are higher. The characteristic features of each generation, each employee's personality and their individual attitudes are considered important factors. Employees are expected to possess adequate knowledge (including expertise), to be highly efficient, self-disciplined, ready for teleworking, able to selforganize their work and to achieve their self-set objectives independently. The ability to establish contacts and retrieve information from the environment, as well as conduct cooperation with other teams in order to identify customers' needs, are both considered important. The distinction between superiors and subordinates becomes blurred, which facilitates free communication.

Successful workforce management involves conscious investment in developing the employees' knowledge and skills and an effective use of their inherent intellectual potential. It is important to recognize and understand that each person is an individual being with their individual consciousness, specific personality traits, aptitudes, abilities, knowledge, experience and skills that they contribute to the organization. Workforce diversity can be a source of success and tangible benefits to the organization if these assets are managed effectively. The main goal of diversity management is to create working conditions and an organizational culture model where employees will have a chance to share their knowledge and learn from each other which, in turn, leads to making better use of their talents and abilities.

\section{MANAGING GENERATIONS IN DIVERSITY MANAGEMENT}

Many companies operating in the Polish market still treat managing the so-called intellectual capital as meaningless marketing slogans or one-off ad hoc actions taken without any specific aim. The same can be said about diversity which often appears as a vague catchword used in company brochures. The twenty-first century forces companies to take a different perspective, related mainly to the new ways of communicating and building the company's reputation (image) on trust, particularly in relation to diversity ${ }^{3}$.

It might seem that this issue concerns only large companies, and yet customers, employees or contractors differ even in micro-enterprises. Accordingly, this cause should be embraced by each company, regardless of its size or the sector in which it operates.

\subsection{The diversity of stakeholders' expectations}

Gone are the times when the company's strategy was shaped by the owners whose sole purpose was profit. Currently, in order to gain a competitive edge and/or a stable market position, a company's strategic planning must incorporate the requirements and expectations of all stakeholders, including loyal customers, loyal employees and the social environment of the company.

This raises the need for reconciliation of purposes and perspectives of different groups, as well as assertiveness in relation to the expectations of partners who tend to demand taking actions that are inconsistent

3 Diversity encompasses all aspects that make people look different or alike, both the explicit - such as gender, age or race - and the implicit ones, like sexual orientation, ethnicity, (dis)ability, skills, education, professional experience, attitudes to life, lifestyles, learning styles, etc. 
with the company values and ensure only short-term gains. Therefore, it is worthwhile to define the key company stakeholders - both internal and external.

\subsection{Diversity among generations ${ }^{4}$}

Managing intergenerational conflicts is not an easy task - companies have been dealing with them since the dawn of time. The generations currently active on the labour market possess different characteristics and attitudes. The X Generation, which holds differing views on work ethics and took part in the struggle for democracy, should be able to effectively manage the generations of their children and grandchildren, the members of which are very different from themselves. However, the X Generation will soon be forced to work as their subordinates and negotiate with them. This presents a challenge which encompasses managing various attitudes, views, values and skills. Members of the X Generation are loyal and experienced. They may be somewhat impatient, driven by their personal needs, but possess technological competences which are necessary to attain success in the modern age. Well thought-out mentoring and coaching programmes are one method of managing this area of diversity, as they combine a transfer of knowledge with teaching communication skills necessary in a global world. It is important to battle stereotypes which have arisen around the Y Generation - young employees who, even among members of their own generation, differ in individual characteristics, attitudes and values.

\section{FACTS AND MYTHS CONCERNING THE Y GENERATION - A MANAGERIAL PERSPECTIVE}

A number of human resource management theories should be brought up when presenting the profile of a Y Generation employee. Many aspects of these theories (searching for a purpose in work, integrating the private and professional life, etc.) were obviously drawn from Schein's career anchor theory (Schein, 1990). These include mainly: autonomy/independence (the desire to be one's own master and to work at a freelychosen pace), entrepreneurial creativity (searching for a work environment which allows for expressing one's creative capabilities), pure challenge (the desire to overcome obstacles and solve complicated problems) and the lifestyle anchor (the need to integrate one's career and lifestyle).

Other aspects of human resource management (searching for feedback, group thinking, as well as elements that regard careers as a means of self-fulfilment, integration of one's private and professional life or opportunism) are all part of various means/techniques of managing said resources. They are, in fact, aimed mainly at individualization whose importance has been increasing over the last few decades (Pichault and Nizet, 2000). Therefore, the Y Generation profile clearly shows that adopting an individualized human resource management model would be ideally suited to the aspirations of its members.

The results of the authors' study, juxtaposing stereotypes about the Y Generation with employers' opinions, are presented in Table 1.

\footnotetext{
4 Currently, members of three generations are active on the labour market: The Baby Boomers (born between 1946 and 1964), the X Generation (1965-1980) and the Y Generation (born after 1981). Conflicts occur mainly between members of the last two.
} 
Identifying the Y Generation's distinctness on the labour market - comparative analysis results

\begin{tabular}{|c|c|c|c|}
\hline $\begin{array}{c}\text { The attitudes and values } \\
\text { of the Y Generation (research } \\
\text { categories) }\end{array}$ & Description of each category & $\begin{array}{c}\text { Subcategories (further } \\
\text { details concerning } \\
\text { each category) }\end{array}$ & $\begin{array}{c}\text { Comparison results - } \\
\text { differences between the Y } \\
\text { Generation and other genera- } \\
\text { tions }\end{array}$ \\
\hline $\begin{array}{l}\text { Searching for a purpose } \\
\text { in work }\end{array}$ & $\begin{array}{l}\text { A moral and civic purpose, a need to } \\
\text { carry out meaningful work }\end{array}$ & $\begin{array}{l}\text { A sense of being use- } \\
\text { ful to others }\end{array}$ & no \\
\hline \multirow[t]{4}{*}{ A need of self-fulfilment } & \multirow{4}{*}{$\begin{array}{l}\text { Being interested in one's job and the } \\
\text { challenges it involves, expectations } \\
\text { concerning further education, a posi- } \\
\text { tive attitude towards work }\end{array}$} & $\begin{array}{l}\text { Pursuing a clear } \\
\text { personal project }\end{array}$ & no \\
\hline & & $\begin{array}{l}\text { Development of com- } \\
\text { petences }\end{array}$ & yes \\
\hline & & \begin{tabular}{|l|}
$\begin{array}{l}\text { Opportunities for self- } \\
\text { development }\end{array}$ \\
\end{tabular} & no \\
\hline & & \begin{tabular}{|l|} 
Attaching importance \\
to lifelong education
\end{tabular} & no \\
\hline \multirow[t]{2}{*}{ Searching for feedback } & \multirow{2}{*}{$\begin{array}{l}\text { A need for immediate financial } \\
\text { gratification or promotion, achiev- } \\
\text { ing goals, searching for feedback } \\
\text { concerning job duties }\end{array}$} & A need for gratitude & no \\
\hline & & $\begin{array}{l}\text { Worries about a suf- } \\
\text { ficient net salary }\end{array}$ & no \\
\hline \multirow{3}{*}{$\begin{array}{l}\text { Integrating one's private and } \\
\text { professional life }\end{array}$} & \multirow{3}{*}{$\begin{array}{l}\text { Lack of differentiation between } \\
\text { work and free time, attaching a lot } \\
\text { of importance to free time, entertain- } \\
\text { ment, friends, family; searching for } \\
\text { pleasure and possibilities of personal } \\
\text { development at work, the ability to } \\
\text { handle multiple tasks }\end{array}$} & Work-life balance & no \\
\hline & & $\begin{array}{l}\text { Being able to plan } \\
\text { one's work schedule }\end{array}$ & no \\
\hline & & $\begin{array}{l}\text { A fear of not finding } \\
\text { the desired job }\end{array}$ & yes \\
\hline \multirow[t]{3}{*}{ Opportunism } & \multirow{3}{*}{$\begin{array}{l}\text { "Chasing about with a timetable } \\
\text { in hand", opportunism, freelancer } \\
\text { behaviour, individualism, self-con- } \\
\text { fidence, a need to strengthen one's } \\
\text { position }\end{array}$} & $\begin{array}{l}\text { Individualistic be- } \\
\text { haviour is considered } \\
\text { discouraging }\end{array}$ & no \\
\hline & & \begin{tabular}{|l|} 
Building one's own \\
future and self-depen- \\
dence
\end{tabular} & no \\
\hline & & $\begin{array}{l}\text { A lack of respect for } \\
\text { ethics and values }\end{array}$ & yes \\
\hline \multirow[t]{2}{*}{ Group thinking } & \multirow[t]{2}{*}{$\begin{array}{l}\text { Being interested in teamwork and } \\
\text { cooperation }\end{array}$} & $\begin{array}{l}\text { Together means } \\
\text { stronger }\end{array}$ & no \\
\hline & & $\begin{array}{l}\text { Solidarity and group } \\
\text { thinking }\end{array}$ & no \\
\hline \multirow[t]{2}{*}{$\begin{array}{l}\text { Weak loyalty towards institu- } \\
\text { tions }\end{array}$} & \multirow[t]{2}{*}{$\begin{array}{l}\text { Weak identification with the com- } \\
\text { pany, mistrust towards authority and } \\
\text { institutions }\end{array}$} & $\begin{array}{l}\text { A need for frequent } \\
\text { changes in environ- } \\
\text { ment }\end{array}$ & yes \\
\hline & & Job security & no \\
\hline $\begin{array}{l}\text { Finding it difficult to plan for } \\
\text { the future }\end{array}$ & $\begin{array}{l}\text { An uncertain outlook on the future, } \\
\text { difficulties in planning one's own } \\
\text { future, troubles with commitment } \\
\text { and making decisions, "tomorrow } \\
\text { never comes" }\end{array}$ & $\begin{array}{l}\text { Expecting the } \\
\text { company to display } \\
\text { innovation and bright } \\
\text { perspectives for the } \\
\text { future }\end{array}$ & no \\
\hline
\end{tabular}

Source: M. Baran, M. Kłos, Pokolenie Y - mity i prawdy w kontekście zarzadzania pokoleniami,

(Generation $Y-$ Myths and Facts in the Context of Intergenerational Management),

a paper prepared for the 2014 Summer School of Management conference. 
Based on research results and literature, it can be stated that the widespread stereotypes about Y Generation employees are often false. What is more, members of the Y Generation approach careers in a similar manner to members of other generations. However, there is a number of characteristics that are strongly associated with the Y Generation. These include: autonomy/independence, entrepreneurial creativity. As well as the following attitudes: searching for a purpose in work (being useful to others), a need of self-fulfilment (pursuing a clear personal project, opportunities for personal development, attaching importance to lifelong education and integrating one's private and professional life which makes it possible to strike a balance between free time and work - all of these are true for members of all generations, including the Y generation. The similarities do not end there - members of the Y generation, just like the generations that came before them, are worried about their employment possibilities and reject opportunistic behaviour (individualistic behaviour is considered discouraging).

These results were then verified and evaluated by a group of different level managers. A selection of the study results are presented in Table 2 which combines hypothetical characteristics of the $Y$ generation with the managers' opinions.

Table 2

Managerial recommendations - managing the Y Generation

\begin{tabular}{|l|l|}
\hline \multicolumn{1}{|c|}{ Generation Y characteristic } & \multicolumn{1}{|c|}{ Recommended attitudes towards members of the Y Generation } \\
\hline Searching for a purpose in work & $\begin{array}{l}\text { Provide a clear explanation of the purpose and importance of the tasks at hand, as well } \\
\text { as the individual job position's impact on the company's results }\end{array}$ \\
\hline The need of self-fulfilment & $\begin{array}{l}\text { Provide information about possible promotion prospects and/or other benefits associ- } \\
\text { ated with reaching ambitious goals with a clearly laid out set of criteria. }\end{array}$ \\
\hline Searching for feedback & $\begin{array}{l}\text { Reward and highlight the most noteworthy short-term achievements, utilize group } \\
\text { discussions to stimulate and encourage finding ways in which others could better } \\
\text { themselves }\end{array}$ \\
\hline $\begin{array}{l}\text { Integrating one's private and } \\
\text { professional life }\end{array}$ & $\begin{array}{l}\text { Make working hours more flexible and take steps to make work enjoyable (e.g. by } \\
\text { holding various corporate events) while providing constant reminders about workplace } \\
\text { "'norms", i.e. what is appropriate and what is not. }\end{array}$ \\
\hline Opportunism & $\begin{array}{l}\text { Provide constructive criticism on a regular basis and make your employees used to } \\
\text { accepting it }\end{array}$ \\
\hline Group thinking & Facilitate team-building and encourage cooperation \\
\hline $\begin{array}{l}\text { Weak loyalty towards institu- } \\
\text { tions }\end{array}$ & $\begin{array}{l}\text { Abandon the myth of integration and loyalty towards organizations, as well as methods } \\
\text { of career management based solely on self-development }\end{array}$ \\
\hline $\begin{array}{l}\text { Finding it difficult to plan for } \\
\text { the future }\end{array}$ & Create numerous opportunities of getting involved in various projects \\
\hline Passion for new technologies & Encourage the use of IT equipment, both at work and outside of it \\
\hline
\end{tabular}

Source: Authors' research

An analysis of managerial expectations towards a more individualised human resource management policy (in the context of diversity management) shows that they are not any different for the Y Generation: searching for feedback, group thinking and a number of aforementioned aspects (a need of self-fulfilment, integrating one's private and professional life, a rejection of opportunism) apply to all three generations.

The respondents indicated that members of the Y Generation are different in that they require regular changes of environment (which does not necessarily mean leaving for another company), feel the need to raise their competences, wish their company to adhere to certain values (respecting creativity and ethics) 
and remain worried about employment opportunities (fear of not finding the desired job). This stems from the fact that very few companies require their employees to do what that they are best at doing, assign tasks that take advantage of their natural talents, strengths, passions and interests. Some companies employ tools which help in determining the individual's talent and potential.

\section{CONCLUSIONS}

Intergenerational cooperation can be described as dynamic which is especially evident in the fact that changes can be anticipated by taking early action. The knowledge management process plays a key part within an organization. It supports the spread of knowledge among all employees, constantly adapting to the changing needs of the environment, by utilizing the knowledge and experience of the organization's workforce. Therefore, conscious management of broadly-defined diversity translates into the company's business strategy and has an impact on predefining competitive factors. Such diversification serves to support the company's communications, implementation of new tools and conducting research on reputation (e.g. by using the 360 degrees method). It also affects the company's organizational structure and facilitates the introduction of a cooperation-friendly atmosphere within it. However, this requires company owners and decision makers to change their habits and old ways of thinking. Practice shows that this is the most difficult part of the entire process. Nevertheless, when the necessary effort is put in, advantages can be gained from utilizing all aspects of diversity which, in simple terms, translates into a return on investment.

\section{REFERENCES}

Bratnicki, M. (2000), Kompetencje przedsiębiorstwa. Od okréśenia kompetencji do zbudowania strategii, Warszawa: Agencja Wydawnicza Placet, p. 14.

Dwojacki, P., Nogalski, B., Sikorski, C. (1999), Zarządzanie w nowych czasach, Przeglad Organizacji, No. 9, p. 11.

Hamel, G., Prahalad, C.K. (1996), Competing for the Future, Boston, Massachusetts: Harvard Business School Press, p. 24.

Koźmiński, A. K. (2004), Zarządzanie w warunkach niepewności. Podręcznik dla zaawansowanych, Warszawa: PWN, p. 93.

Łoboda, M., Sitko-Lutek, A. (2007), Kompetencje i luka kompetencyjna organizacji, w: Polskie firmy wobec globalizacji. Luka kompetencyjna, Sitko-Lutek A., (red.), Warszawa: Wydawnictwo Naukowe PWN, pp. 21-23.

Pierścionek, Z. (2003), Strategie konkurencji i rozwoju przedsiębiorstw, Warszawa: PWN, p. 177.

Raport Barometru różnorodności (I), available at

www.diversityindex.pl/Content/uploaded/files/DI_Barometr_Roznorodnosci_raport(1).pdf, referred on 2014-05-10.

Raport Economist Intelligence Unit (EIU) - nt. różnorodności w biznesie, available at www.linkedin.com/company/linkleaders-communication-ङ-consulting, referred on 2014-05-15.

Quinn, J.B., Hilmer, F.G. (1994), Strategic Outsourcing, Sloan Management Review, Vol. 35, No. 4, pp. 45-47.

Schein, E.H. (1990), Career Anchors: Discovering Your Real Values, San Diego (California): Pfeiffer \& Company, p. 35.

Pichault, F. \& Nizet, J. (2000), Les pratiques de gestion des ressources humaines. Approches contingente et politique, Paris: Seuil, col. Points/Essais Sciences humaines, p. 15. 